\title{
ECONOMIC EFFICIENCY AND INTERNAL COMPETITIVE ADVANTAGES OF GRAIN PRODUCTION IN THE CENTRAL REGION OF UKRAINE
}

Nataliia Kovalenko ${ }^{\mathrm{a}}$, Vitalii Kovalenko ${ }^{\mathrm{b}}$, Taras Hutsolc, Yulia Ievstafiieva ${ }^{\mathrm{d}}$, Anastasiia Polishchuk $^{\mathrm{e}}$

a Faculty of Agrarian Management, Department of Administrative Management and Foreign Economic Activity, National University of Life and Environmental Sciences of Ukraine, Kyiv, Ukraine, email: n.kovalenko@it.nubip.edu.ua, ORCID 0000-0003-0621-8214

b Agrobiological Faculty, Department of fodder production, reclamation and meteorology, National University of Life and Environmental Sciences of Ukraine, Kyiv, Ukraine, e-mail: kovalenko_v@nubip.edu.ua, ORCID 0000-0001-7158-825X

c Institute of Energy, State Agrarian and Engineering University in Podilia, Kamianets-Podilskyi, Ukraine, e-mail: pro-gp@pdatu.edu.ua, ORCID 0000-0002-9086-3672

d Faculty of Veterinary Medicine and Technology in Animal Husbandry, State Agrarian and Engineering University in Podilia, Ukraine, Kamianets-Podilskyi, Ukraine, e-mail: pp.nika22@ukr.net, ORCID 0000-0001-5914-893X

e Postgraduate Student, State Agrarian and Engineering University in Podilia, Ukraine, Kamianets-Podilskyi, Ukraine, e-mail: anastasiya300595@gmail.com

* Corresponding author: e-mail: kovalenko_v@nubip.edu.ua

\begin{tabular}{|c|c|}
\hline ARTICLE INFO & ABSTRACT \\
\hline $\begin{array}{l}\text { Article history: } \\
\text { Received: March } 2021 \\
\text { Received in the revised form: April } \\
2021 \\
\text { Accepted: May } 2021 \\
\text { Keywords: } \\
\text { economic efficiency, } \\
\text { internal competitive advantages, } \\
\text { grain production }\end{array}$ & $\begin{array}{l}\text { The paper discusses competitiveness of the agro-industrial sector, } \\
\text { which is a multifaceted concept that characterizes its ability to compete } \\
\text { in both domestic and foreign markets. Ukraine has significant opportu- } \\
\text { nities to develop the agricultural sector and turn it into a highly efficient } \\
\text { branch of economy. Favorable soil and climate conditions, and fertile } \\
\text { land contribute to its further development, obtaining agricultural crops } \\
\text { in volumes sufficient to meet domestic needs and build export potential. } \\
\text { The production process of agricultural goods takes longer than in in- } \\
\text { dustry. Therefore, at the stage of determination of the production pro- } \\
\text { gram of an agricultural enterprise, it is very difficult to respond on time } \\
\text { to changes in consumer demand and increase the product competitive- } \\
\text { ness within the already established production schemes in the markets. } \\
\text { Therefore, the purpose of our study is to evaluate the effectiveness of } \\
\text { growing the studied crops in a typical farm in Central Ukraine and offer } \\
\text { a roadmap for making management decisions when planning a produc- } \\
\text { tion program. For this purpose, a method based on calculations of the } \\
\text { gross margin, total expenses, production thresholds, profitability, and } \\
\text { payback of production factors was chosen. }\end{array}$ \\
\hline
\end{tabular}




\section{Introduction}

The main task of the agro-industrial complex is to achieve sustainable growth in agricultural production, reliable provision of the country with food and raw materials, and to combine the efforts of all sectors to achieve high final results. Formation of competitive advantages of agricultural enterprises increases competitiveness of the agricultural sector of the economy, and, therefore, contributes to solution of problems related to food security of the country (Godfray et al., 2010; Durbach and Stewart, 2012; Falcone et al., 2016; Forman and Peniwati, 1998; Noya et al., 2015; Parihar et al., 2016).

The climate change we are witnessing now is a reality, although it is not a scientifically proven fact of global warming. More often than not, warming occurs during winter, and the summer climate in most regions remains unchanged, often even cooler. Thus, we need to be more technologically prudent in sowing winter crops. In general, Ukraine supplies its needs with food grain, but it lacks high-quality grain, strong and durum wheat. Therefore, we need to prioritize the production of these grains by increasing their sown areas (Brown and Funk, 2008; Gathala et al., 2015; Parra-Lopez et al., 2007; Reynolds et al., 2010).

Grain farming has the main role in the country's agricultural production and guarantees its food security. It is considered as a sector of strategic importance. The grain is not only the raw material for the bakery, confectionery, and cereal industries, but also for the alcohol, brewing and medical ones. Animal husbandry development depends on the efficiency of grain production. At the same time, grain farming fosters resource and export potentials, taking into account the country`s economic development and its economic flourish. In a nutshell, improving the efficiency of grain production is a crucial task that must be addressed not only at the state but also at the regional levels (Chaves et al., 2007; Kuzmenko et al., 2016; Lobell et al., 2008;Perederiy and Kovalenko, 2018; Prechsl et al., 2017; Promentilla et al., 2008).

The initiated study aims at evaluation of the effectiveness of growing crops studied by us at a typical farm in the central part of Ukraine - winter wheat, winter barley, spring barley, corn for grain. The calculations made will enable us to compare the efficiency of grain production in this region and others, both within the country and with the indicators of foreign countries.

\section{Materials and Methods}

A method based on calculations of the gross margin, total expenses, production thresholds and profitability and payback of factors of production: land, capital and labor was chosen for our research.

The gross margin is calculated as a difference between the cost of a commodity product and variable costs in a particular production process.

$$
\text { Gross Margin = Output }- \text { Proportional Variable Costs }
$$

This is the contribution of a particular type of a product to cover fixed costs and to profit the entire enterprise. Thus, it is an on-farm indicator of competitiveness. The gross margin is always calculated for a specific unit, such as $1 \mathrm{ha}$, usually for one year. The same fixed and overhead expenses, which will be distributed proportionally over the entire area at the end of the year, will be deducted from the margin income. The production threshold is the value of 
Economic efficiency...

variable costs per unit of production. Thus, it shows what the price of a particular product should be in order for its production to be economically viable in the short term.

The gross margin calculation was performed in the MAX program (developed by the University of Applied Sciences Weihenstephan-Triesdorf (Germany)), which allows calculation of the main economic production indicators and making management decisions.

Fig. 1 shows an example of the gross margin calculation form we used.

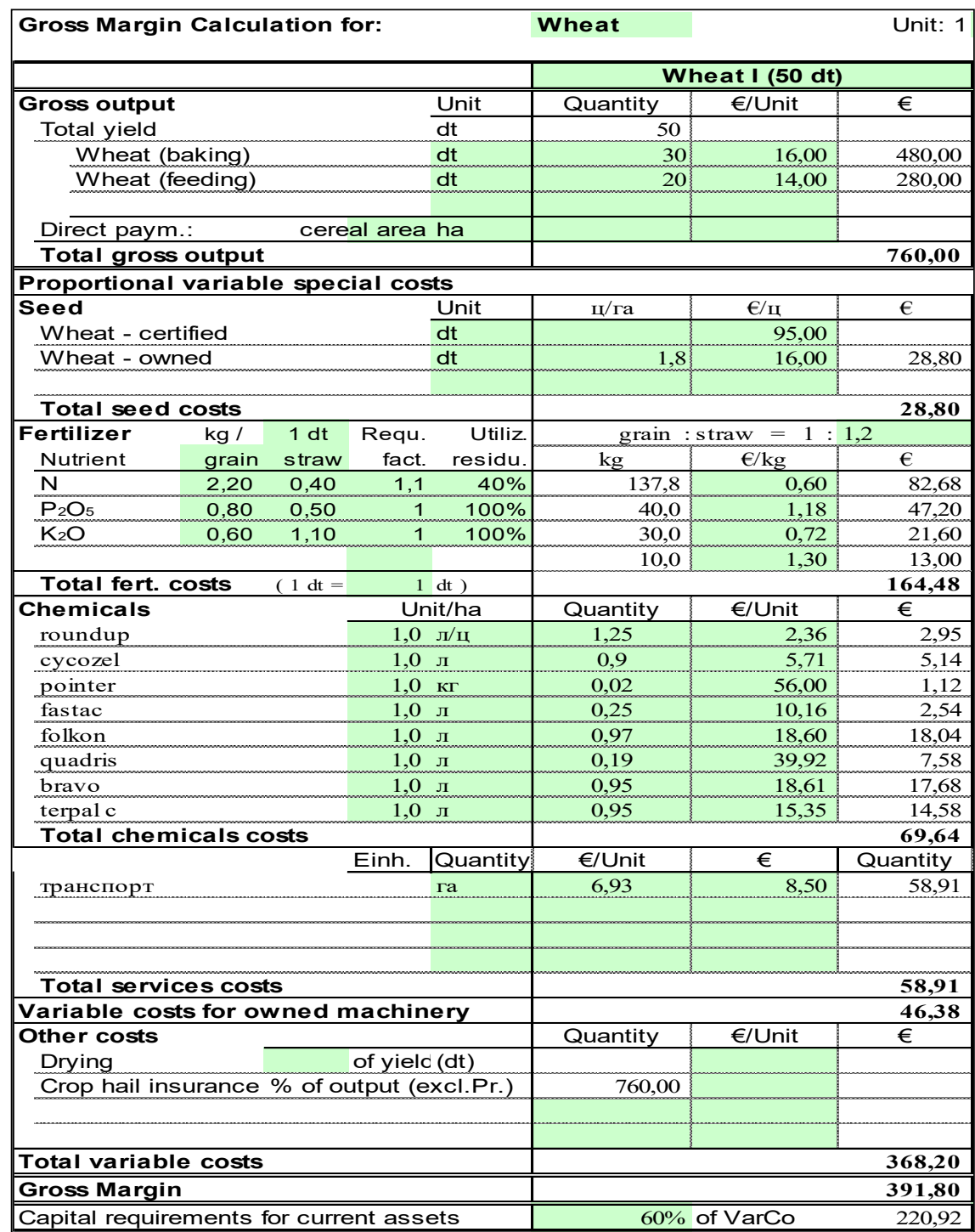

Figure 1. Gross Margin Calculation for Winter Wheat 
The production threshold (1.2) answers the question whether further production of a particular product (or its expansion) makes a short-term economic sense or not. It means the point at which the marginal cost of a given product exceeds the marginal cost incurred in its production and thus the marginal profit gains a positive value. Relative to the unit of production, this means that the marginal cost is lower than the product price. The production threshold is thus the lower margin of the production price (Kovalenko and Kovalenko, 2019; Kuzmenko et al., 2016; Ivanyshyn et al., 2018; Neumann et al., 2010).

$$
\text { Production threshold }=\frac{\text { Variable costs per unit }(1 \mathrm{ha})-\text { Value of spinoff products }}{\text { Amount produced per unit }(1 \mathrm{ha})}
$$

The profitability threshold (1.3) represents the total cost per unit of production (the average cost). The profitability threshold answers the question: what should be the price of a particular product in order for an entrepreneur to make a profit from its production. The profitability threshold is also called the profit threshold (Halushko and Shtroebel, 2005).

$$
\text { Profitability threshold }=\frac{\text { Total costs per unit }(1 \mathrm{ha})-\text { Value of spin }- \text { off products }}{\text { Amount produced per unit }(1 \mathrm{ha})}
$$

The longer the planning period, the more fixed items of expenditure become variables. The production threshold is increasingly equated to the profitability threshold as the planning period increases.

Payback of factors of production (land, capital, labor) (1.5) is the payback of these factors through production processes. It is defined as the difference between sales revenue and all expenses other than the cost of the factor itself (Kuzmenko at al., 2016; Mudryk and Werle, 2018).

Output (production $\times$ price, direct paym.)

-all costs excluding the respective factor costs

$=$ Payback to factor per unit of the enterprise $(1 \mathrm{ha})$

Payback of factors of production $=\frac{\text { Payback to factor per unit of the enterprise }(1 \mathrm{ha})}{\text { Factor input per unit of the enterprise }(1 \mathrm{ha})}$

As an example of a farm, we selected an enterprise in the central region of Ukraine, which is typical for the following indicators (based on statistics) - the size of the land resource, the availability of hired workers, the list of crops grown. The enterprise has almost 10000 hectares of arable land, about 90 workers, it is engaged in the production of cereals and industrial crops, has a dairy herd, and produces basic feed. The calculations were carried out for the 2018-2019 marketing year.

\section{Research results and discussion}

In the studied enterprise, we analyzed the economic efficiency of production of grain crops namely winter wheat, winter barley, spring barley and corn for grain. 
According to practical calculations, the gross margin includes only the costs of production means (seeds, fertilizers, plant protection, costs of mechanization, fuel, etc.) and services since they are usually referred to as variable expenses. Expenses on working capital, land, rights of production and sale (interest, labor remuneration, rent), as well as expenses on fixed assets (depreciation, interest rates, etc.,), general production expenses are not included.

The amount of the gross margin is used in the production process to cover fixed and overhead costs, as well as to generate profit. Thus, the gross margin value shows how much the total profit will increase if the production process is expanded by 1 unit, provided that all the necessary production factors are available. The gross margin of production of 1 ha of winter wheat in the studied farm is $396.72 € \cdot \mathrm{ha}^{-1}$. That is, if we increase the production of winter wheat for each additional hectare, we will get $396.72 €$.

When calculating the gross margin of winter barley, spring barley and corn for grain, we received the following gross margin per 1 ha $-407.81 €, 262.83 €, 479.79 €$, respectively (Fig. 2). According to the above methodology, the difference between the gross margin of crops is an internal indicator of product competitiveness, and in order to make a profit for each of the crops, we will deduct a proportional amount of fixed costs from the gross margin. Therefore, the difference in margin income will reflect the future difference in profit. In our economy, the highest gross margin belongs to the production of corn for grain, which reflects the overall situation in the region.

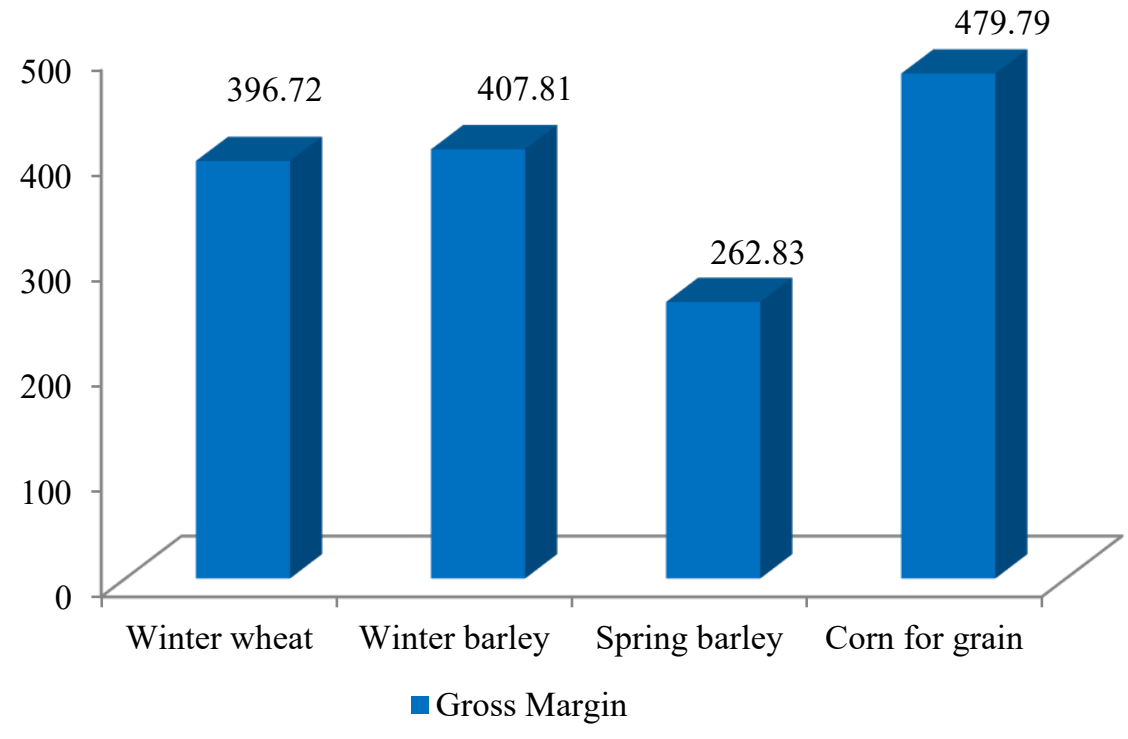

Figure 2. Calculations of gross margin of grain crops, $\left(€ \cdot h a^{-1}\right)$

Before determining the profit, all expenses are determined, and then they are added in turn and form the total costs. In addition to the variable expenses already calculated in the gross margin, the following are added: the cost of capital invested in working capital; remuneration of labor (productive work); land use costs; expenses for purchasing rights (licenses) 
for production and delivery of products; depreciation, maintenance costs of fixed assets, insurance, and the like; payment for administrative work; other special fixed costs and overheads (Kuzmenko and Perederiy, 2015).

The total production costs of winter wheat, winter barley, spring barley, and corn for grain in a typical farm were respectively $609.94 € \cdot \mathrm{ha}^{-1}, 686.16 € \cdot \mathrm{ha}^{-1}, 491.04 € \cdot \mathrm{ha}^{-1}$, and 721.99 $€ \cdot$ ha $^{-1}$ (Fig. 2). So, the most expensive crop on the farm is corn for grain, and the least expensive is spring barley. The difference between profit and net profit is that in calculating profit, opportunity costs for own production resources are not taken into account, whereas in calculating business income they are taken into account. A positive profit is the amount remaining after covering the costs of attracted resources: raw materials, buildings, equipment, wages, interest payments, as well as the return on own production resources (family labor, equity, land). In our calculations (Fig. 3) we received the following profit indicators: winter wheat 193.47€ $\cdot \mathrm{ha}^{-1}$, winter barley $-202.22 € \cdot \mathrm{ha}^{-1}$, spring barley $-63.76 € \cdot \mathrm{ha}^{-1}$ and corn for grain $273.76 € \cdot \mathrm{ha}^{-1}$. Indicators of net profit were $-150.06 € \cdot \mathrm{ha}^{-1}$ for winter wheat, $153.84 € \cdot \mathrm{ha}^{-1}$ for winter barley, $30.96 € \cdot \mathrm{ha}^{-1}$ for spring barley and $223.01 € \cdot \mathrm{ha}^{-1}$ for corn for grain.

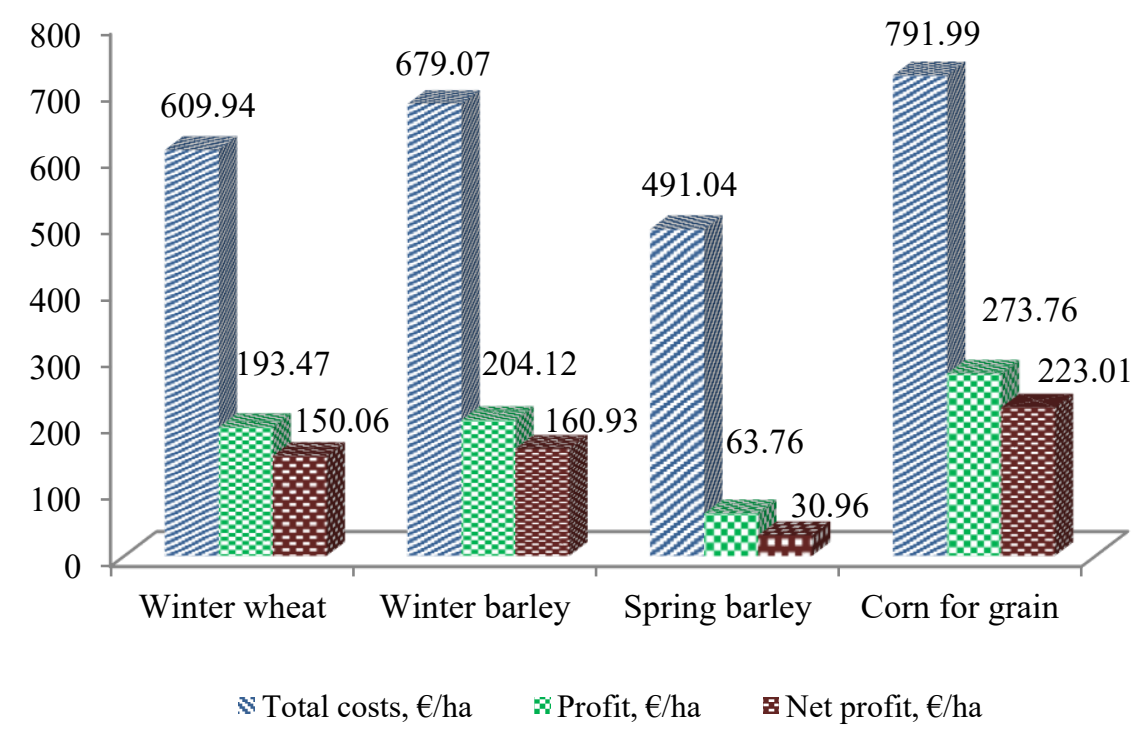

Figure 3. Calculations of total costs, profit, net profit of grain crops, $\left(€ \cdot h a^{-1}\right)$

The enterprise under study, in contrast to farms, has a small amount of its own resources involved - this is capital, whereas the land is leased (shares) and all workers are hired. A positive business income means all factors of production, including own, pay off, and for own factors of production, this means that in this case they are used more effectively than in the alternative. 
Economic efficiency...

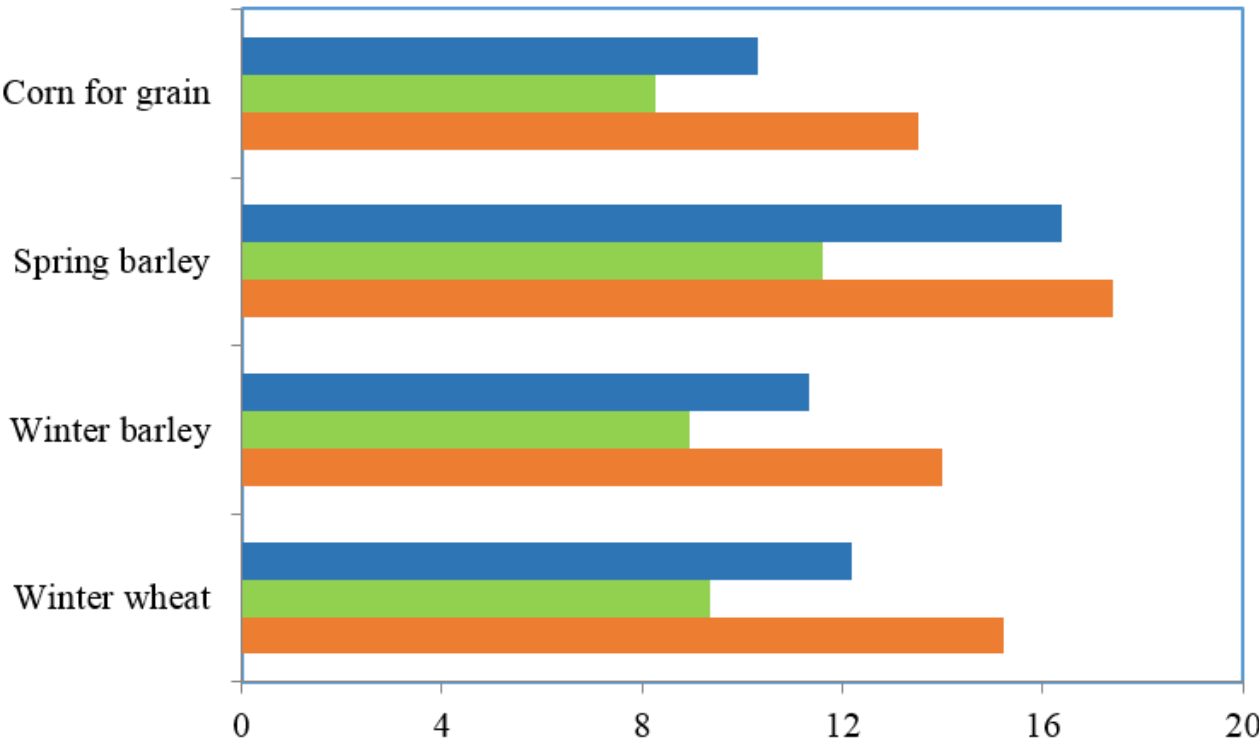

- Profitability threshold, $€ / \mathrm{dt} \backsim$ Production threshold, $€ / \mathrm{dt} \backsim$ Price, $€ / \mathrm{dt}$

Figure 4. Calculations of the threshold production and the profitability threshold of grain crops, $\left(\epsilon \cdot d t^{-1}\right)$

The threshold of production and the profitability threshold. When calculating the production threshold for the main production processes, you can see (Fig. 4) that the threshold for winter wheat production is $9.35 € \cdot \mathrm{dt}^{-1}$. This means that in order for winter wheat production to be economically feasible in the short term, the minimum price for winter wheat must be $9.35 € \cdot \mathrm{dt}^{-1}$. Our selling price is $15.20 € \cdot d \mathrm{dt}^{-1}$. Therefore, we can conclude that the winter wheat production in the short term is reasonable, all variable costs are covered.

Having considered the calculation of thresholds for the production of winter barley, spring barley, corn for grain, it is clear that, as in the production of winter wheat, these crops cover all the costs for them. The price at which all expenses are covered is called the profitability threshold. If the price exceeds the profitability threshold, then a business income is achieved (Perederiy and Kovalenko, 2018). The profitability threshold for the production of 1 deciton of winter wheat is $12.20 € \cdot \mathrm{dt}^{-1}$. The sales price is calculated to be $15.20 € \cdot \mathrm{dt}^{-1}$. Therefore, the production of winter wheat in the long term will be profitable. That is, the minimum price should not be lower than $12.20 € \cdot \mathrm{dt}^{-1}$ for the farm to make a profit in the long term. The profitability threshold for the production of 1 deciton of winter barley is $11.44 € \cdot \mathrm{dt}^{-1}$. The sales price is calculated to be $14.00 € \cdot \mathrm{dt}^{-1}$. Winter barley production is profitable in the long term.

The profitability threshold for the production of 1 deciton of spring barley is $16.37 € \cdot d t^{-1}$. The sales price is calculated to be $17.40 € \cdot \mathrm{dt}^{-1}$. The production of spring barley is also profitable in the long term. Corn for grain also covers all expenses, the price is $13.50 € \cdot \mathrm{dt}^{-1}$ with 
the total cost of $10.31 € \cdot \mathrm{dt}^{-1}$. Payback of production factors and their productivity. Payback of production factors such as labor, land, capital represents the payback of these factors through production processes.

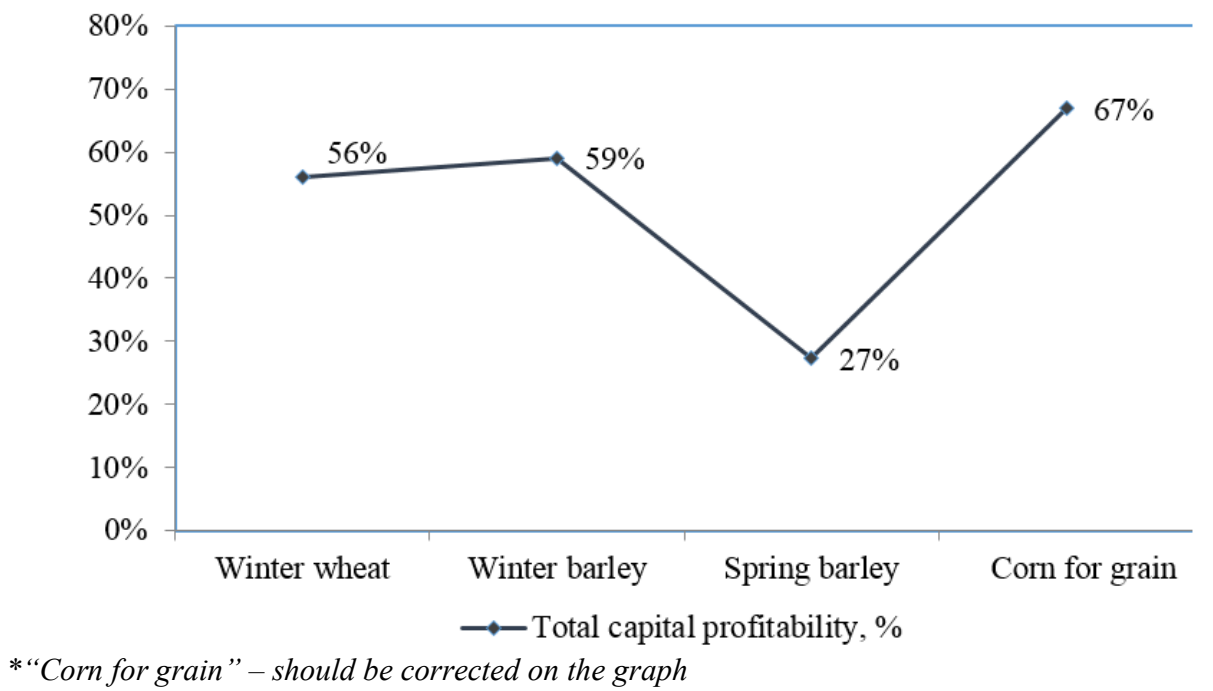

Figure 5. Payback of capital in the production of grain crops, (\%)

The payback factor is calculated in stages for land ( $€$ per 1 ha), total labor ( $€$ per 1 personhour) and total capital ( $€$ per $1000 €$ of the average invested capital). Consider the payback of capital factor for each crop (Fig.5). The return on the invested capital for winter wheat is $56 \%$, winter barley $-53 \%$, spring barley $-27 \%$, corn for grain $-67 \%$ and is the highest indicator at the farm.

Payback of labor spent (Fig. 6) when growing winter wheat is $78.57 € \cdot$ person-hour ${ }^{-1}$, that is, for each person-hour spent, it creates products for $78.57 €$. When growing 1 ha of winter barley, spring barley, corn for grain, the payback is $72.68 € \cdot$ person-hour $^{-1}, 19.13 € \cdot$ personhour $^{-1}, 113.35 € \cdot$ person-hour ${ }^{-1}$ respectively.

Payback of 1 ha of land (Fig. 7) used for growing winter wheat is $216.06 € \cdot \mathrm{ha}^{-1}$, for winter barley $-219.84 € \cdot h^{-1}$, for spring barley $-96.96 € \cdot \mathrm{ha}^{-1}$, for corn for grain $-289.01 € \cdot \mathrm{ha}^{-1}$. This means that it is more profitable to conduct their own production on this land than to lease land at $66 € \cdot \mathrm{ha}^{-1}$. 
Economic efficiency...

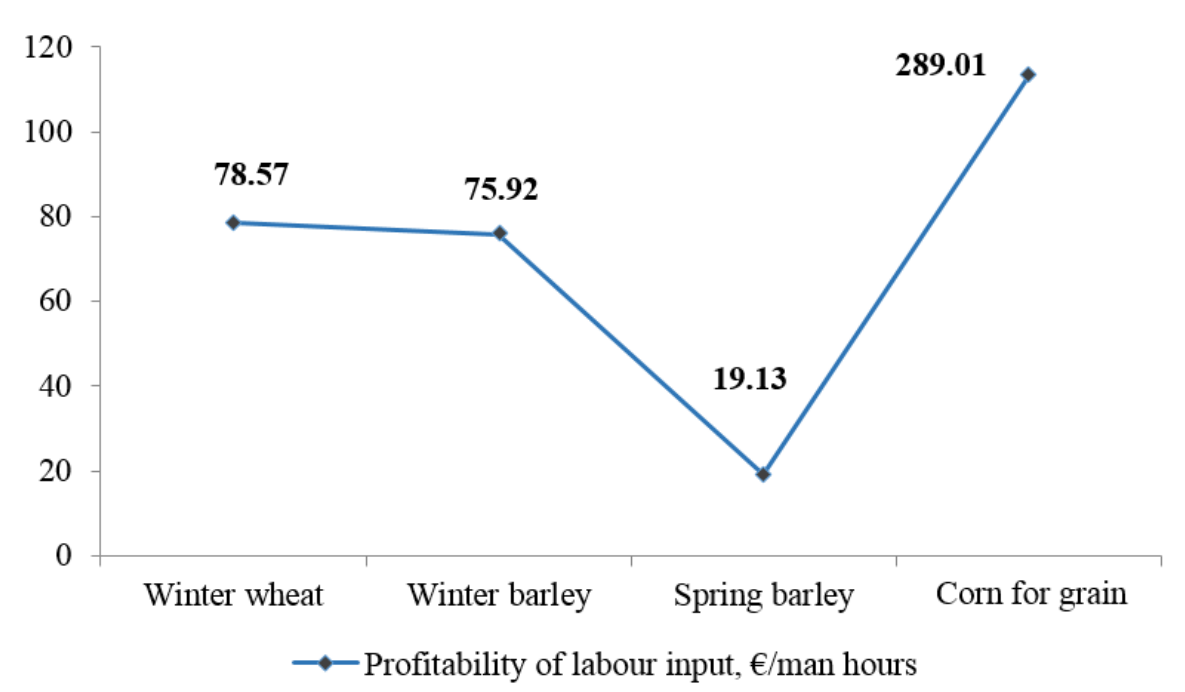

Figure 6. Payback of labor in the production of grain crops, $(€ \cdot$ person-hour-1)

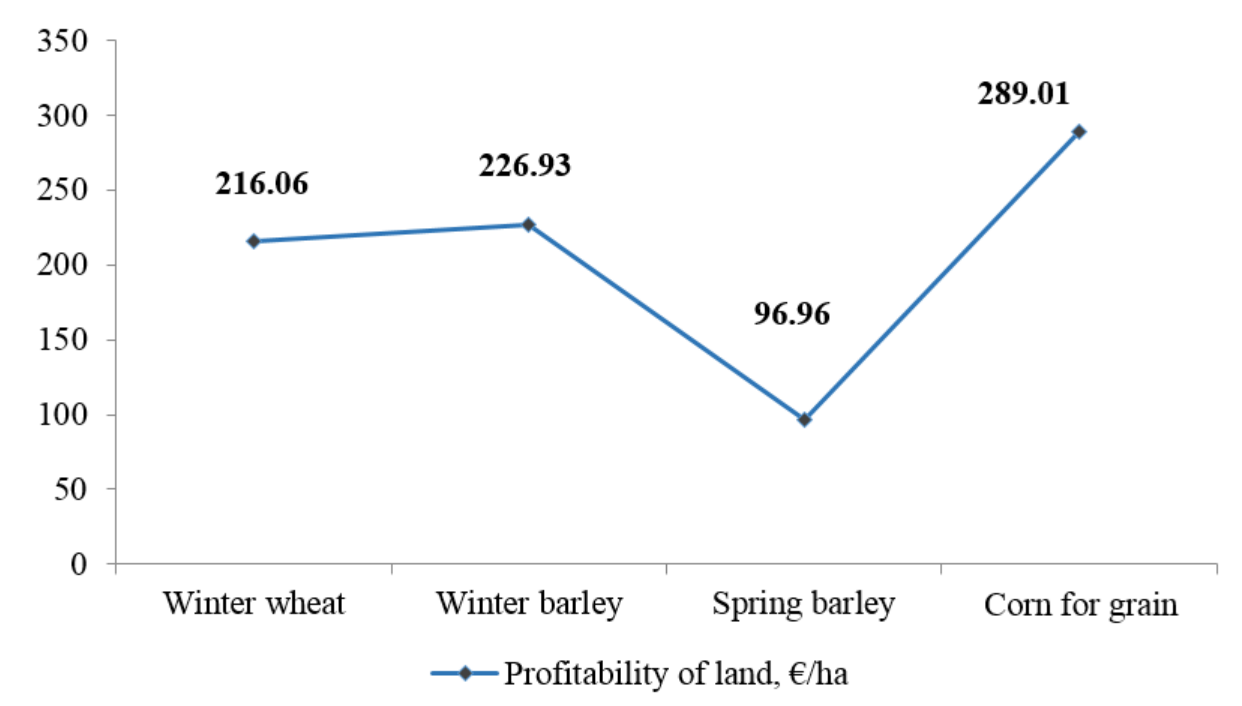

Figure 7. Land payback in the production of grain crops, $\left(€ \cdot h a^{-1}\right)$ 


\section{Discussion}

The proposed approach to calculating the economic performance of an enterprise is universal since it is based on calculating the gross margin. At the moment, in Ukraine and the CIS countries, calculations based on the cost price are more often used, it also makes it possible to obtain results in the calculation of profit (Kuzmenko et al., 2016). But generally accepted calculations have certain drawbacks - often enterprises do not calculate the net profit, thus they do not evaluate their own factors of production and the efficiency of their use. This is particularly negative for farms from an economic point of view, where many of their own production factors are involved (Kovalenko and Kovalenko, 2019; Mykhailov et al, 2020; Neumann et al., 2010).

The second argument in favor of our calculation method is that the marginal income is a universal indicator that can be calculated at any time and make a managerial decision on adjusting production, rather than waiting for the end of the year and calculating profit (Perederiy and Kovalenko, 2018; Promentilla et al., 2008).

It should also be noted that this calculation methodology is widely used in Europe, it makes it possible to compare the main production results for crops in various countries (Durbach, and Stewart, 2012; Reynolds, 2010).

\section{Conclusion}

Having made calculations for grain production based on a typical enterprise in the Central region of Ukraine, we can draw the following conclusions:

1. In order to determine which crop at the farm in the future will be the most profitable and will have the greatest payback, it is not necessary to wait for the end of the economic year to calculate the profit.

2. At any given time, an economist can calculate the internal competitiveness of any crop based on the gross margin - variable costs, as opposed to constant costs, can be calculated by the enterprise at the beginning of the economic period. As our example showed, corn for grain in the calculation of gross margin occupied the first position, and also received the highest payback in the final calculations.

3. The most profitable for 2019 remains the production of corn for grain, as evidenced by all the indicators of economic efficiency calculated above.

4. All grain crops are subject to fluctuations in the global prices, so we do not recommend that the farm refuses to produce winter wheat and winter barley. The profitability indicators for these crops are also quite high. Regarding the production of spring barley, we can suggest replacing it with more competitive products with the Eastern cultivation technology. 


\section{References}

Brown, M.E., and Funk, C.C. (2008). Food security under climate change. Science 319, 580-581.

Chaves, M.M., Santos, T.P., Souse, C.R., Ortuno, M.F., Rodriguez, M.L., Lopes, C.M., Maroco, J.P.,

Pereira, J.S. (2007). Deficit irrigation in grapevine improves water-use efficiency while controlling vigour and production quality. Annals Applied Biology, 150, 237-252. https://doi.org/10.1111/j.1744 7348.2006.00123.x.

Godfray, H.C.J., Beddington, J.R., Crute, I.R., Haddad, Lawrence, L.D., Muir, J.F. Pretty, J., Robinson, S., Thomas, S.M., Toulmin, C. (2010). Food security: the challenge of feeding 9 billion people. Science, 327, 812-818.

Halushko, V., Shtroebel, H. (2005). Production Economics. Vinnytsia, Nova Knyga, pp. 400.

Durbach, I. N., Stewart, T.J. (2012). Modeling uncertainty in multi-criteria decision analysis. European Journal of Operational Research, 223, 1e14. https://doi.org/10.1016/j.ejor.2012.04.038.

Falcone, G., De Luca, A.I., Stillitano, T., Strano, A., Romeo, G., Gulisano, G. (2016). Assessment of environmental and economic impacts of vine-growing combining life cycle assessment, life cycle costing and multicriterial analysis. Sustainability, 8, 793.https://doi.org/10.3390/su8080793.

Forman, E., Peniwati, K. (1998). Aggregating individual judgments and priorities with the analytic hierarchy process. European Journal of Operational Research, 108, pp. 165-169. https://doi.org/10.1016/S0377-2217(97)00244-0.

Gathala, M.K., Timsina, J., Islam, M.S., Rahman, M.M., Hossain, M.I., Harun-Ar-Rashid, M., Ghosh, A.K., Krupnik, T.J., Tiwari, T.P., McDonald, A. (2015). Conservation agriculture based tillage and crop establishment options can maintain farmers' yields and increase profits in South Asia's ricemaize systems: evidence from Bangladesh. Field Crops Research, 172, pp. 85-98. https://doi.org/10.1016/j.fcr.2014.12.003.

Ivanyshyn, V., Kucher, O., Bilyk, T. (2018). Marketing strategy formation for the development of organic production in the Ukraine. Proceedings of the International Scientific Conference "Economic Sciences for Agribusiness and Rural Economy", 1, 34-39. https://doi.org/10.22630/ESARE .2018.1.3

Kovalenko, V., Kovalenko, N. (2019). Planning of enterprise fodder base. Scientific journal "Plant and Soil Science", 286, 35-42.

Kuzmenko, S., Perederiy, N. (2015). Market of rapeseed: economic and bioenergetic perspective Monograph. Komprynt, Kyiv, pp. 227.

Kuzmenko, S., Perederiy, N., Labenko, O. (2016). Market trends of oilseeds production in Ukraine. The Agri-Food Value Chain: Challenges for Natural Resources Management and Society. International Scientific Days, Slovak Republic, Nitra, pp. 54-61.

Lobell, D. B., Burke, M. B., Tebaldi, C., Mastrandrea, M. D., Falcon, W. P. and Naylor, R. L. (2008). Prioritizing climate change adaptation needs for food security in 2030. Science, 319, 607-610.

Mudryk, K., Werle, S. (2018). Renewable energy sources: engineering, technology, innovation. Springer International Publishing, pp. 834. https://doi.org/10.1007/978-3-319-72371-6

Mykhailov, Ye., Golebiewski, J., Kiurchev, S., Hutsol, T., Kolodii, O., Nurek, T., Glowacki, Sz., Zadosna, N., Verkholantseva, V., Palianychka, N., Kucher, O. (2020). Economic and technical efficiency of sunflower seed processing. Monograph. Warszawa, pp. 158. https://doi.org/10.22630/ SGGW.WE.9788375839340

Neumann, K., Verburg, P. H., Stehfest, E., Müller, C. (2010). The yield gap of global grain production: a spatial analysis. Agricultural Systems, 103(5), 316-326. https://doi.org/10.1016/ j.agsy.2010. 02.004 .

Noya, I., Gonzalez-García, S., Bacenetti, J., Arroja, L., Moreira, M.T., (2015). Comparative life cycle assessment of three representative feed cereals production in the Po Valley (Italy). Journal of Cleaner Production, 99, pp. 250-265. https://doi.org/10.1016/j.jclepro.2015.03.001. 
Parihar, C. M., Jat, S. L., Singh, A .K., Kumar, B., Pradhan, S., Pooniya, V., Dhauja, A.,Chaudhary, V., Jat, M. L., Jat, R.K. (2016). Conservation agriculture in irrigated intensive maize-based systems of north-western India: effects on crop yields water productivity and economic profitability. Field Crops Research, 193, 104-116. https://doi.org/10.1016/j.fcr.2016.03.013.

Parra-Lopez, C., Calatrava-Requena, J., de-Haro-Gimenez, T. (2007). A multi-criteria evaluation of the environmental performances of conventional, organic and integrated olive-growing systems in the south of Spain based on experts' knowledge. Renewable Agriculture and Food Systems, 22, 189e203. https://doi.org/10.1017/S1742170507001731.

Perederiy, N., Kovalenko, V. (2018). Economic Basis for the Creation of Fodder Base of the Enterprise. International Scientific Days, Slovak Republic, Nitra, 840-851.

Prechsl, U. E., Wittwer, R., van der Heijden, M. G., Lüscher, G., Jeanneret, P.,Nemecek, T. (2017). Assessing the environmental impacts of cropping systems and cover crops: life cycle assessment of FAST, a long-term arable farming field experiment. Agricultural Systems, 157, 39-50. https://doi.org/10.1016/j.agsy.2017.06.011.

Promentilla, M.A.B., Furuichi, T., Ishii, K., Tanikawa, N. (2008). A fuzzy analytic network process for multicriteria evaluation of contaminated site remedial countermeasures. Journal of Environmental Management, 88 (3), 479e495. https://doi.org/10.1016/j.jenvman.2007.03.013.

Reynolds, M. P., Bonnett, D., Chapman, S., Furbank, R., Manes, Y., Mather, D., et al. (2010). Raising yield potential of wheat: (I) overview of a consortium approach and breeding strategies. Journal of Experimental Botany, 62, 439-452. https://doi.org/10.1093/jxb/erq311.

\section{EFEKTYWNOŚĆ EKONOMICZNA I WEWNETRZNA PRZEWAGA KONKURENCYJNA PRODUKCJI ZBÓŻ NA TERENIE ŚRODKOWEJ UKRAINY}

Streszczenie. W pracy przedstawiono rozważania na temat konkurencyjności sektora rolno-przemysłowego, która jest pojęciem wielopłaszczyznowym, które opisuje zdolność konkurowania na rynku krajowym i rynkach zagranicznych. Ukraina posiada istotne możliwości rozwoju sektora rolnego i zamiany go w wysoko wydajną gałąź gospodarki. Korzystne warunki glebowe i klimatyczne oraz żyzna ziemia wpływają na jego dalszy rozwój, uzyskiwanie plonów w ilościach wystarczających na pokrycie potrzeb krajowych i zbudowania potencjału eksportowego. Proces produkcji dóbr rolniczych zajmuje więcej czasu niż w przemyśle. Zatem, na etapie przygotowywania programu produkcyjnego przedsiębiorstwa rolnego, trudno jest w odpowiednim czasie zareagować na zmiany potrzeb klientów i wzrost konkurencyjności produktu w już określonych schematach produkcyjnych na rynkach. Dlatego, celem pracy jest zbadanie efektywności uprawy badanych roślin w typowym gospodarstwie na obszarze centralnej Ukrainy i zaoferowanie planu działania w zakresie podejmowania decyzji kierowniczych podczas ustalania programu produkcyjnego. W tym celu wybrano metodę opartą na obliczaniu marży brutto, wszystkich wydatków, progów produkcyjnych i opłacalności oraz zwrotu czynników produkcyjnych.

Słowa kluczowe: efektywność ekonomiczna, wewnętrzna przewaga konkurencyjna, produkcja zbóż 